\title{
UPAYA MENINGKATAN KEMAMPUAN GURU DALAM MENYUSUN ADMINISTRASI PEMBELAJARAN MELALUI SUPERVISI AKADEMIK PADA MASA PANDEMI COVID-19 DI SDN 1 WANASABA DAYA KECAMATAN WANASABA
}

\author{
NASIR \\ SDN 1 Wanasaba Kabupaten Lombok Timur \\ Nasir.nasir12@gmail.com
}

\begin{abstract}
ABSTRAK
Tujuan dari penelitian tindakan sekolah (PTS) ini adalah untuk mengetahui sejauh mana supervisi yang dilakukan oleh kepala sekolah yang diikuti dengan pemberian pembinaan/perlakuan terhadap guru-guru sasaran dapat meningkatkan kemampuan guru tersebut dalam menyusun administrasi pembelajaran. Dalam penelitian tindakan sekolah (PTS) ini dilakukan dalam 2 siklus, dari hasil tindakan yang dilakukan terbukti dapat meningkatkan kemampuan guru dengan mencapai standar ideal. Pada siklus I peningkatan kemampuan guru dalam menyusun administrasi pembelajaran mencapai sekitar $33,33 \%$, pada siklus II dapat meningkat menjadi $100 \%$. Skor rata-rata yang diperoleh setelah dilakukan supervisi kelas pada siklus I sebesar 71,33 dan meningkat pada siklus II menjadi 83,33, berarti ada peningkatan sebesar 12 dan tingkat ketuntasan secara kelompok/klasikal pada siklus I mencapai 33,33\% dan pada siklus II meningkat menjadi $100 \%$. Hasil penelitian tindakan sekolah ini menunjukkan bahwa pembinaan kepala sekolah dapat meningkatkan kemampuan guru dalam menyusun administrasi pembelajaran.
\end{abstract}

Kata Kunci: kemampuan guru, supervise akademik

\section{ABSTRACT}

The purpose of this school action research (PTS) is to determine the extent to which the supervision carried out by the principal followed by the provision of guidance/treatment to the target teachers can improve the ability of these teachers in preparing learning administration. In this school action research (PTS) it was conducted in 2 cycles, from the results of the actions taken it was proven to be able to improve the ability of teachers by achieving ideal standards. In the first cycle the increase in the ability of teachers in preparing learning administration reached about $33.33 \%$, in the second cycle it could increase to $100 \%$. The average score obtained after class supervision was carried out in the first cycle was 71.33 and increased in the second cycle to 83.33 , meaning that there was an increase of 12 and the level of completeness as a group/classical in the first cycle reached $33.33 \%$ and in the first cycle it was $33.33 \%$. II increased to $100 \%$. The results of this school action research indicate that the coaching of the principal can improve the ability of teachers in preparing learning administration.

Keywords: teacher ability, academic supervision

\section{PENDAHULUAN}

Kegiatan organisasi pendidikan tidak akan mencapai tujuan yang ditetapkan apabila dijalankan tanpa pengawasan. Rendahnya komitmen para pendidik semakin memperkuat alas an pentingnya pengawasan yang efektif dalam mengelola pembelajaran di kelas (Sagala, dkk, 2016). Peraturan Menteri Nasional Nomor 13 tahun 2007 tentang Standar kepala sekolah/madrasah menegaskan bahwa seorang kepala sekolah/madrasah harus memiliki lima dimensi kompetensi minimal yaitu kompetensi kepribadian, manajerial, kewirausahaan, supervisi dan sosial (Naway, dkk, 2017).

Undang-undang Republik Indonesia nomor 14 tahun 2005 tentang guru dan dosen pasal 20 ayat (b) mengamanatkan bahwa dalam rangka melaksanakan tugas keprofesionalannya, guru berkewajiban meningkatkan dan mengembangkan kualifikasi akademik dan kompetensi serta berkelanjutan sejalan dengan perkembangan ilmu pengetahuan, teknologi dan seni (Alamsyah, 
Vol. 1 No. 3 Desember 2021 e-ISSN : 2797-3344 P-ISSN : 2797-3336

dkk, 2020). Pernyataan undang-undang di atas pada intinya mempersyaratkan guru untuk memiliki (1) kualifikasi akademik minimal S1 atau D-IV. (2) Kompetensi sebagai agen pembelajaran yaitu kompetensi paedagogik, kepribadian, social, dan professional. (3) Sertifikat pendidik. Undang-undang ini diharapkan memberikan suatu kesempatan yang tepat bagi guru untuk meningkatkan profesionalismenya secara berkelanjutan melalui pelatihan, penelitian, penulisan karya ilmiah dan kegiatan professional lainnya (Jahidi, 2017). Berbagai upaya untuk meningkatkan kinerja guru, antara lain melalui pelatihan instruktur, peningkatan sarana prasarana dan peningkatan kinerja guru dalam melaksanakan pembelajaran dikelas.

Berdasarkan PP 19 Tahun 2005 Pasal 20 dinyatakan bahwa; "Perencanaan proses pembelajaran meliputi silabus dan rencana pelaksanaan pembelajaran yang memuat sekurangkurangnya tujuan pembelajaran, materi ajar, metode pengajaran, sumber belajar, dan penilaian hasil belajar". Sesuai dengan permendiknas Nomor 41 tahun 2007 tentang Standar Proses dijelaskan bahwa RPP dijabarkan dari silabus untuk mengarahkan kegiatan belajar peserta didik dalam upaya mencapai KD (Andiyanto, dkk, 2017). Setiap guru pada satuan pendidikan berkewajiban menyusun RPP secara lengkap dan sistematis agar pembelajaran berlangsung secara interaktif, inspiratif, menyenangkan, menantang, memotivasi peserta didik untuk berpartisipasi aktif, serta memberikan ruang yang cukup bagi prakarsa, kreativitas, dan kemandirian sesuai dengan bakat, minat, dan perkembangan fisik serta psikologis peserta didik (Khaerani, 2016).

Berdasarkan peraturan pemerintah nomor 74 tahun 2008, pasal 52 ayat (1) yang mencakup kegiatan pokok yaitu merencanakan pembelajaran, menilai hasil pembelajaran, membimbing dan melatih peserta didik, serta melaksanakan tugas tambahan yang melekat pada pelaksanaan tugas pokok, yaitu sebagai administrastor (Darmadi, 2016). Akan tetapi kenyataannya tidak semua guru mengajar melakukan itu, masih ada guru mengajar tanpa menyusun kelengkapan administrasi mengajar, sehingga dapat kita bayangkan bagaimana hasil pembelajaran yang dicapai, sudah barang tentu tujuan pembelajaran yang telah diamanatkan oleh undang-undang tidak akan tercapai tanpa direncanakan (Sujemanwati, 2019).

Berdasarkan hasil pemantauan kepala sekolah, masih banyak teman-teman guru yang belum mampu melaksanakan tugas pokoknya dengan baik, karena kurang kemampuannya dalam menyusun administrasi pembelajaran. Permasalahan yang sering dihadapi guru di SD Negeri 1 Wanasaba Daya tidak lepas dari beberapa masalah diatas seperti guru yang kurang mampu menyusun RPP, tidak sesuai antara RPP dengan apa yang dijelaskan dalam proses pembelajaran, guru belum mampu menggunakan strategi pembelajaran yang bervariasi, kemampuan dalam pembelajaran masih rendah. Di SD Negeri 1 Wanasaba Daya pada awal pelaksanaan supervisi ada beberapa guru masih perlu bimbingan dalam pembuatan RPP termasuk pada komponen-komponennya yaitu merumuskan tujuan, pembelajaran, bahan/ materi ajar, strategi pembelajaran dan penilaian.

Berangkat dari permasalahan tersebut, diperlukan pembinaan terhadap guru yang teridentifikasi masih memiliki masalah baik pada proses pembuatan RPP maupun dalam proses pembelajaran. Salah satu yang dilakukan paling penting adalah melalui supervisi akademik oleh Kepala Sekolah. Supervisi akademik yang dimaksud disini tidak hanya berhenti pada pencermatan dokumen RPP dan pemantauan kegiatan pembelajaran, tetapi juga dilanjutkan dengan menindaklanjuti setiap temuan, maka dalam hal ini perlu diutarakan bagaimana bimbingan terhadap guru tersebut, maka setelah itu dilakukan bimbingan untuk bisa menyusun RPP dengan baik dan sempurna sesuai dengan tujuan pendidikan dan standar proses. Maka dalam hal ini perlu dipaparkan bagaimana caranya untuk melakukan supervisi yaitu: (1). Secara individual, pelaksanaan supervisi perseorangan terhadap guru. (2). Secara kelompok, pelaksanaan supervisi ditujuakan pada dua orang atau lebih dengan masalah yang sama. Supervisi individual dilakukan dengan cara kunjungan kelas, observasi kelas, pemantauan individual, kunjungan antar kelas, dan menilai diri sendiri. Cara pelaksanaan kunjungan kelas antara lain: dengan atau tanpa pemberitahuan terlebihdahulu, permintaan guru yang bersangkutan, telah memiliki instrumen atau catatan tujuan kunjungan kelas harus jelas. 
Vol. 1 No. 3 Desember 2021 e-ISSN : 2797-3344 P-ISSN : 2797-3336

Tahapan-tahapan kunjungan kelas, persiapan, merencanakan waktu, sasaran, dan cara mengobservasi, pengamatan selama kunjungan, memberikan hasil dan tindak lanjut.

\section{METODE PENELITIAN}

Jenis penelitian ini adalah penelitian tindakan Sekolah (PTS). Penelitian tindakan sekolah (PTS) merupakan suatu proses investigasi terkendali yang berdaur ulang dan bersifat reflektif mandiri yang dilakukan oleh kepala sekolah yang memiliki tujuan untuk melakukan perbaikan-perbaikan terhadap sistem, cara kerja, proses, isi, Kemampuan, atau situasi pembelajaran. Penelitian tindakan sekolah (PTS) dan dilaksanakan pada semester genap tahun pelajaran 2020/2021 ini.

Penelitian tindakan sekolah ini dilaksanakan di SDN 1 Wanasaba Daya kabupaten Lombok Timur yang merupakan tempat tugas peneliti. Penelitian ini dilaksanakan dengan menggunakan dua siklus, dengan setiap siklusnya dilaksanakan proses pembimbingan berupa Penerapan model pembelajaran kemudian dilaksanakan observasi/penilaian berupa supervisi proses pembelajaran. Penelitian ini dilaksanakan selama kurang lebih tiga bulan, yaitu mulai Bulan Juli sampai dengan September 2021.

Subyek pada penelitian ini adalah guru SDN 1 Wanasaba Daya, yang terdiri dari 3 orang guru yaitu guru kelas 4, 5, dan kelas 6. Pada penelitian tindakan sekolah ini, memiliki cirri utama yaitu terdapat siklus-siklus yang tiap siklusnya memiliki tahapan-tahapan yaitu: a) perencanaan tindakan (planning), b) tindakan (acting), c) pengamatan (observasing), d) refleksi (reflecting). Sumber data penelitian ini berasal dari peneliti, observer, dan guru sasaran penelitian pada semester genap di SDN 3 Beririjarak Kecamatan Wanasaba.

\section{HASIL DAN PEMBAHASAN}

\section{Siklus I}

Tahap Perencanaan, Pada tahap ini peneliti mempersiapkan perangkat pembinaan yang terdiri dari rencana pembinaan 1, Instrumen 1, Evaluasi 1 dan alat-alat pembinaan yang mendukung. Selain itu juga dipersiapkan lembar observasi pengolaan pembelajaran.

Tahap Kegiatan dan Pelaksanaan, Pelaksanaan kegiatan pembinaan untuk siklus I dilaksanakan tanggal 12 s.d 31 Juli 2021 di SDN 1 Wanasaba Daya Kecamatan Wanasaba. dengan jumlah guru 3 Orang. Dalam hal ini peneliti bertindak sebagai Kepala Sekolah. Adapun proses pembinaan mengacu pada rencana pelajaran yang telah dipersiapkan.

Pengamatan (observasi) dilaksanakan bersamaan dengan pelaksaaan belajar mengajar. Pada akhir proses pembinaan, guru dan kepala sekolah menyepakati waktu pelaksanaan supervisi di kelas dengan tujuan untuk mengetahui tingkat kemampuan guru dalam proses belajar mengajar yang telah dilakukan. Adapun data hasil penelitian pada siklus I. adalah seperti pada tabel berikut :

Tabel 1 Tabel hasil Supervisi Akademik Pada Siklus I

\begin{tabular}{llccc} 
& & \multicolumn{3}{c}{ Keterangan } \\
No & \multicolumn{1}{c}{ Nama Guru } & Skor & Tuntas & $\begin{array}{c}\text { Tidak } \\
\text { Tuntas }\end{array}$ \\
& & 72 & & $\sqrt{ }$ \\
1 & ANWAR, S.Pd & 75 & $\sqrt{ }$ & $\sqrt{ }$ \\
2 & MOH.AYUB, S.Pd & 63 & & - \\
$3 \quad$ SYARIFA ALWIAH & 214 & - & - \\
Jumlah Nilai & 71,33 & - & - \\
Nilai rata-rata & $33,33 \%(=1$ guru $)$ \\
\% Jumlah Guru Yang Mencapai nilai & \\
Supervisi Akademik minimal 75 & & & \\
\hline
\end{tabular}

Dari tabel di atas dapat dijelaskan bahwa dengan menerapkan supervisi akademik kepala sekolah diperoleh nilai rata-rata Kemampuan guru adalah 71,33 dan ada 1 orang guru dari 3 orang sudah meningkat mutunya dalam proses belajar mengajar. Hasil tersebut 
Vol. 1 No. 3 Desember 2021 e-ISSN : 2797-3344 P-ISSN : 2797-3336

menunjukkan bahwa pada siklus pertama secara kelompok guru(sekolah) belum meningkat mutunya, karena guru yang memperoleh nilai $\geq 75$ hanya sebesar $33,33 \%$ artinya lebih kecil dari persentase ketuntasan yang dikehendaki yaitu sebesar $\geq 85 \%$. Hal ini disebabkan karena guru masih merasa baru dan belum mengerti apa yang dimaksudkan dan dijelaskan oleh Kepala Sekolah dalam pembinaan kaitan dengan penerapan model pembelajaranoleh guru-guru tersebut masih agak mengalami kesulitan dalam penyampaian materi pembelajaran.

Refleksi, Dalam pelaksanaan kegiatan belajar mengajar diperoleh informasi dari hasil pengamatan sebagai berikut: 1) Kepala Sekolah kurang maksimal dalam memotivasi guru dan dalam menyampaikan tujuan pembinaan. 2) Guru kurang mampu dalam pengelolaan waktu. 3) Guru masih kurang begitu antusias dan termotivasi selama pembelajaran berlangsung.

Revisi Rancangan, Pelaksanaan kegiatan pembinaan pada siklus I ini masih terdapat kekurangan, sehingga perlu adanya revisi untuk dilakukan pada siklus berikutnya. 1) Kepala Sekolah perlu lebih terampil dalam memotivasi guru dan lebih jelas dalam menyampaikan tujuan pembinaan. Di mana guru diajak untuk terlibat langsung dalam setiap kegiatan yang dilakukan. 2) Guru perlu mendistribusikan waktu secara baik dengan menambahkan informasiinformasi yang dirasa perlu dan memberi catatan. 3) Kepala Sekolah harus lebih terampil dan bersemangat dalam memotivasi guru sehingga guru bisa lebih antusias.

\section{Siklus II}

Tahap perencanaan, Pada tahap ini peneliti mempersiapkan perangkat pembinaan yang terdiri dari rencana pembinaan 2 , lembar observasi dan alat-alat pembinaan yang mendukung.

Tahap kegiatan dan pelaksanaan, Pelaksanaan kegiatan pembinaan untuk siklus II dilaksanakan pada tanggal 16 s.d 31 Agustus 2021 di SDN 1 Wanasaba Daya Kecamatan Wanasaba Kabupaten Lombok Timur tahun pelajaran 2021/2022 Dalam hal ini peneliti bertindak sebagai Kepala Sekolah. Adapun proses pembinaan mengacu pada rencana pembinaan dengan memperhatikan revisi pada siklus I, sehingga kesalahan atau kekurangan pada siklus I tidak terulang lagi pada siklus II. Pengamatan (observasi) dilaksanakan bersamaan dengan pelaksanaan belajar mengajar.

Pada akhir proses pembinaan, guru dan kepala sekolah menyepakati waktu supervisi di kelas dengan tujuan untuk mengetahui peningkatan kemampuan guru dalam proses pembinaan yang telah dilakukan. Instrumen yang digunakan adalah tes formatif II. Adapun data hasil penelitian pada siklus II adalah sebagai berikut :

Tabel 2 Distribusi Skor Hasil Supervisi Akademik Kemampuan Guru menerapkan model pembelajaran Pada Siklus II

\begin{tabular}{llccc}
\hline & & \multicolumn{3}{c}{ Keterangan } \\
No & Nama Guru & Skor & Tuntas & $\begin{array}{c}\text { Tidak } \\
\text { Tuntas }\end{array}$ \\
& & & $\sqrt{ }$ & \\
1 & ANWAR, S.Pd & 91 & $\sqrt{ }$ & \\
2 & MOH.AYUB, S.Pd & 90 & $\sqrt{ }$ & - \\
3 & SYARIFA ALWIAH & 79 & - & - \\
Jumlah Nilai & 250 & 83,33 & - & - \\
Nilai rata-rata & $100 \%(=3$ guru $)$ \\
\% Jumlah Guru Yang Mencapai nilai & \multicolumn{4}{l}{} \\
Supervisi Akademik minimal 75 & - & &
\end{tabular}

Dari tabel di atas diperoleh nilai rata-rata peningkatan kemampuan guru adalah 83,33 dan ketuntasan pembinaan mencapai $100 \%$ atau semua guru matematika yang dijadikan sasaran penelitian sudah meningkat mutunya dalam proses belajar mengajar. Hasil ini menunjukkan bahwa pada siklus II ini ketuntasan belajar 100\%. Dari data-data yang telah diperoleh dapat duraikan sebagai berikut : 1) Selama proses pembinaan Kepala Sekolah telah melaksanakan semua pembinaan dengan baik. Meskipun ada beberapa aspek yang belum sempurna, tetapi persentase pelaksanaannya untuk masing-masing aspek cukup besar. 2) 
Vol. 1 No. 3 Desember 2021 e-ISSN : 2797-3344 P-ISSN : 2797-3336

Berdasarkan data hasil pengamatan diketahui bahwa guru aktif selama proses belajar berlangsung. 3) Kekurangan pada siklus-siklus sebelumnya sudah mengalami perbaikan dan peningkatan sehingga menjadi lebih baik. 4) Hasil pembinaan guru oleh kepala sekolah melalui supervisi akademik pada siklus II mencapai ketuntasan $100 \%$.

Pada siklus II guru telah menerapkan model pembelajaran melalui pembinaan kepala sekolah dengan baik dan dilihat dari aktivitas guru serta hasil pembinaan guru pelaksanaan proses pembinaan sudah berjalan dengan baik. Maka tidak diperlukan revisi terlalu banyak, tetapi yang perlu diperhatikan untuk tindakan selanjutnya adalah memaksimalkan dan mempertahankan apa yang telah ada dengan tujuan agar pada pelaksanaan proses belajar mengajar selanjutnya pembinaan yang dilakukan Kepala Sekolah dapat meningkatkan kemampuan guru dalam proses belajar mengajar dalam menerapkan model pembelajaran sehingga tujuan pembelajaran dapat tercapai. berikut.

Setelah dilakukan tindakan pada siklus 1, dan siklus 2 menunjukkan hasil sebagai

\section{Tabel 3 Analisis Hasil Observasi Kemampuan Guru Pada Siklus I dan Siklus II Melalui} Supervisi Akademik

\begin{tabular}{llcc}
\hline No & Nama & $\begin{array}{c}\text { Skor Perolehan } \\
\text { Pada Siklus I }\end{array}$ & $\begin{array}{c}\text { Skor } \\
\text { Pada Siklus II }\end{array}$ \\
$\begin{array}{llcc}\text { Perolehan } \\
1\end{array} \quad$ ANWAR, S.Pd & 72 & 81 \\
2 & MOH.AYUB, S.Pd & 75 & 90 \\
3 & SYARIFA ALWIAH & 63 & 79 \\
Jumlah Nilai & 209 & 215 \\
Nilai rata-rata & 69,67 & 71,33 \\
\% Jumlah Guru Yang Mencapai nilai & $33,33 \%$ & $33 \%$ \\
supervisi akademik minimal 75 & $(1$ guru $)$ & $(1$ guru $)$ \\
\hline
\end{tabular}

Dari hasil analisis tersebut dapat disimpulkan bahwa : A) Terjadi peningkatan rata-rata hasilkemampuan guru dari siklus I ke siklus II yaitu dari 71,33 menjadi 83,33 ada kenaikan sebesar $=12$. B) Terjadi peningkatan jumlah guru yang mencapai hasil Kemampuan $\geq 75$ dari siklus I ke siklus II yaitu dari 1 orang menjadi 3 orang artinya semua sasaran telah mencapai ketuntasan.

\section{Pembahasan}

Berdasarkan hasil penelitian ini menunjukkan bahwa penerapan model pembelajaran melalui binaan Kepala Sekolah memiliki dampak positif dalam meningkatkan kemampuan guru. Hal ini dapat dilihat dari semakin mantapnya pemahaman guru dari pembinaan yang diberikan oleh kepala sekolah (rata-rata hasil Kemampuan guru meningkat dari siklus I, dan II) yaitu masing-masing 71,33 dan; 83,33. Pada siklus II ketuntasan pembinaan guru secara kelompok telah tercapai.

Berdasarkan analisis data, diperoleh aktivitas guru dalam pembinaan yang dilakukan Kepala Sekolah dalam menerapkan model pembelajaran dalam setiap siklus mengalami peningkatan. Hal ini berdampak positif terhadap peningkatan kemampuan guru yaitu dapat ditunjukkan dengan meningkatnya nilai rata-rata yang dicapai guru pada setiap siklus yang terus mengalami peningkatan.

Berdasarkan analisis data, diperoleh aktivitas guru dan Kepala Sekolah dalam proses pembinaan melalui penerapan model pembelajaran yang paling dominan adalah bekerja dengan menggunakan alat/media, mendengarkan / memperhatikan penjelasan Kepala Sekolah, dan diskusi antar guru antara guru dan Kepala Sekolah. Jadi dapat dikatakan bahwa aktivitas guru dapat dikategorikan aktif. Sedangkan untuk aktivitas Kepala Sekolah selama pembinaan telah melaksanakan langkah-langkah pembinaan pelatihan berkelanjutan dengan baik. Hal ini terlihat dari aktivitas Kepala Sekolah yang muncul di antaranya aktivitas membimbing dan mengamati guru dalam mengerjakan kegiatan pembelajaran, menjelaskan, memberi umpan balik/evaluasi/tanya jawab di mana prosentase untuk aktivitas di atas cukup besar. 
Vol. 1 No. 3 Desember 2021 e-ISSN : 2797-3344 P-ISSN : 2797-3336

Berdasarkan hasil penelitian di atas, maka hasil pembinaan Kepala Sekolah hasilnya sangat baik. Hal itu tampak pada pertemuan pertama dari 3 Orang guru yang hadir pada saat penelitian ini dilakukan ketuntasan pencapaian Kemampuan ideal dari siklus I dan siklus II masing-masing yaitu $33 \%$ meningkat menjadi $100 \%$.

Dari analisis data di atas bahwa pembinaan dalam meningkatkan kemampuan guru dalam menerapkan model pembelajaran melalui pembinaan Kepala Sekolah, yang berarti proses kegiatan belajar mengajar lebih berhasil dan dapat meningkatkan mutunya khususnya di SDN 1 Wanasaba Daya Kecamatan Wanasaba kabupaten Lombok Timur, oleh karena itu diharapkan kepada para guru SDN 1 Wanasaba Daya dapat meningkatkan mutunya dalam melaksanakan pembelajaran di kelas.

Berdasarkan manajemen berbasis sekolah (MBS) dikatakan tuntas apabila guru telah mencapai nilai KKM sebesar 75 mencapai $\geq 83,33 \%$. Sedangkan pada penilitian ini, pencapaian nilai $\geq 75$ pada ( siklus II ) mencapai melebihi target yang ditetapkan dalam MBS yaitu mencapai $100 \%$.

\section{KESIMPULAN}

Dari hasil kegiatan pembinaan yang telah dilakukan selama dua siklus, dan berdasarkan seluruh pembahasan serta analisis yang telah dilakukan dapat disimpulkan sebagai berikut : Penerapan Supervisi Akademik dapat meningkatkan Kemampuan guru dalam memanfaatkan media pembelajaran di SDN 1 Wanasaba Daya Kecamatan Wanasaba tahun pelajaran $2021 / 2022$.

\section{DAFTAR PUSTAKA}

Alamsyah, M., Ahmad, S., \& Harris, H. (2020). Pengaruh Kualifikasi Akademik dan Pengalaman Mengajar terhadap Profesionalisme Guru. Journal of Education Research, 1(3), 1830187.

Andiyanto, T. (2017). Peran Guru Dalam Implementasi Kurikulum 2013: Studi Pada Tk Mentari Kec. Abung Selatan Kab. Lampung Utara. Elementary: Jurnal Ilmiah Pendidikan Dasar, 3(1), 73-78.

Darmadi, H. (2016). Tugas, peran, kompetensi, dan tanggung jawab menjadi guru profesional. Edukasi: Jurnal Pendidikan, 13(2), 161-174.

Jahidi, J. (2017). Kualifikasi dan Kompetensi Guru. Administrasi Pendidikan: Jurnal Ilmiah Mahasiswa Pascasarjana, 2(1), 23-30.

Khaerani, N. C. (2016). Peningkatan Kompetensi Guru dalam Menyusun RPP melalui Kegiatan IHT (in house training). Didaktikum, 17(1).

Naway, F., Letak, P., \& Yusuf, D. (2017). Komunikasi dan Organisasi Pendidikan. Gorontalo: Ideas Publishing.

Sagala, H. S., \& Sos, S. (2016). Memahami Organisasi Pendidikan: Budaya dan Reinventing, Organisasi Pendidikan. Prenada Media.

Sujemanwati, S. (2019). Strategi Guru Sebagai Administrator dalam Membangkitkan Motivasi Belajar Siswa (Doctoral dissertation, Universitas Islam Negeri Alauddin Makassar). 